\title{
The Development of Arbitration in Albanian Legislation, Actual Challenges
}

\author{
Rakel Muçaj \\ European University of Tirana \\ Email: rakel_mucaj2106@hotmail.com
}

\section{Doi:10.5901/mjss.2015.v6n1p347}

\begin{abstract}
During the transition, the Albanian government has faced a number of challenges. These challenges will not only be in the economic sphere, but also in political and legislative aspect as well. As a communist system before the 90s, the Albanian legal regime put a big gap on the provision of rights and obligations for its citizens. With the establishment of free trade, the priority was given to the free entrepreneurship, which operated independently and empowered by the state. The development of new contractual relations resulted in the emergence of a variety of disputes. Albanian businesses already had been given the opportunity, not only to be supported by the usual trials, but also to address their needs to arbitration. This paper aims to determine the evolution and integration of arbitration in the current legislation. Finally, a discussion will identify the current development as well as future challenges.
\end{abstract}

Keywords: arbitration, business, political, disputes, legislation.

\section{Introduction}

In today's global economy, many lawyers and entrepreneurs sooner or later will encourage arbitration, as a concept which may arise as a negotiation or agreement ${ }^{1}$. One of the parties may always define arbitration based on the agreement, excluding ordinary judgment. An agreement which may be created during the birth of a conflict or in the future of the relationship.

After 90', Albanian politics and society faced a transition as effective and difficult at the same time. The Albanian Government changed from a closed totalitarian system towards a greater freedom, as required. Albanian perspective has been and will remain the European Union, which means the tip of the iceberg of democracy in our country. The economic developments enabled the establishment of contracts not only between Albanian citizens but also for foreigners, which reveals the existence of relations with foreign elements. The legal alternatives for resolving these disputes are the trials offered commonly in the majority. Currently the workload of the courts, and the complex nature of trade relations, usually is too costly both in time and money. Business for its nature always requires effective and quick solutions on the dispute.

The arbitration in itself serves as a way of resolving disputes, between one or more parties, which do not always end with satisfying all requirements of the clients. However, most importantly, the conclusion of the arbitration proceedings will have a decision which is binding on the parties. The Albanian state until the 90 's regulated the activity of arbitration only through law No. 7424 dated the 14.11.1990 "On State Arbitration", a highly politicized law, like any other law in that period. Urgent and necessary changes will emerge as a challenge for the Albanian legislator, for a rethinking mode of dispute settlement. Therefore, arbitration in the last decade has shown an increase, being perceived as a neutral mechanism for settling disputes, in a way that the parties continue their relationship in harmony.

\section{An Overview of the Albanian Legislation on Arbitration}

\subsection{The Arbitration Legal Framework during the communism}

The Albania's communist system was established at the end of World War II. Similar to many countries of the Eastern Europe, Albania represented the Socialist Economic model. Like every other activity in that period which was an exclusive property of the state, the institution of arbitration was created as an exclusive state feature also. This "State" arbitration would provide mechanisms for resolving disputes between state enterprises, with a high level of political and administrative control over vessels created to resolve such disputes.

1 Bennett., S C.(2002), "Arbitration: Essential Concepts" Alm publishing, New York, Page 3. 
Decree No. 443 dated the 2 of July, 1947 "On Resolving Property Disputes by Arbitration state shall be considered as the origin of this institution. It was the first organic law for the functioning and operation of arbitration. Throughout the activity of the communist system, the arbitration institution has undergone numerous legislative changes: Decree nr.1872 dated the 07.05.1954 "On state arbitration"; Decree nr.5009 dated the 10.11.1972 "On state arbitration"; Official Journal 1972, no.6, page 75; Decree No.6927, dated the 14.11.1984 "On amendments to the Decree No.5009 "On state arbitration", Official Journal 1984, no.3, page $45^{2}$. Arbitration as a concept has not been specified in the Civil Code of Procedure of the Republic of Albania in 1982, after it was provided with a separate law, the Law No. 7424 dated the 14.11.1990 "On state arbitration". The title of the law itself reveals its politicized terms, as any law in that period. At this point the state arbitration was decided as a permanent structure. A characteristic of this law was that on the one hand there was jurisdiction to resolve property, contractual or non-contractual issues, between institutions and state entities. Thus, we see that there was the issue of the state against the state. On the other hand it had a voluntary jurisdiction for the resolution of property issues between the state and private enterprises. This brought the existence of a state-private bridge. In the case of jurisdictions, voluntary arbitration states that intervention will be based only upon the agreement of the parties.

The scope of this law established that the issues will be under the jurisdiction of arbitration, by the request of only two parties ${ }^{3}$. At this point the contractual character of arbitration emerges. To seek arbitration, there must exist consent of the parties and an agreement between them, because otherwise no one shall be subjected to its jurisdiction. These principles are still today confirmed on national law and international arbitration.

Another important element in this period would be the actual elimination of confidentiality, as one of the fundamental principles of arbitration. The arbitration proceedings not only would not be private, but they would be developed even in the presence of other persons, like chairman of the cooperative, workers ${ }^{4}$, etc. Arbitration state at this period by way of proceeding does not affirm democratic principles and private nature of arbitration, as numerous international legislation assess confidentiality as an indivisible part of the process.

The recognition and enforcement of arbitral decisions in this period was final and binding. The decision was addressed to the institution of the State Bank and other financial institutions, obligating the execution of the arbitration decision. According to the law, the decision can be implemented voluntarily by the parties in the process, within a time limit, because otherwise compulsory execution would be applied5.

\subsection{The Arbitration Legal Framework after the transition.}

After the 90's, economic and political changes would require a reorganization of the institution of arbitration, which by that time was controlled by the state and politicized, transforming into an institution of disputes.

The Albanian legislation does not have a specific law on arbitration, but it is included in the Civil Code of Procedure, indicating that it is seen as a process that is regulated and operates as part of the judicial system. So, it was subject to the same rules as if it were a genuine judicial process. The Albanian legislation on arbitration is summarized on 39 articles of the Civil Code of Procedure (C.C.P). Chapter 1 provides the general provisions, Chapter II the formation of the arbitration tribunal, Chapter III the arbitration proceedings, Chapter IV the court decision on arbitration, and Chapter V the appeal against the decision of the arbitral tribunal.

The existence of the arbitration must have two conditions (1) Parties are domicile or reside in the Republic of Albania, (2) the place of the arbitration procedure. There are no definitions on commercial arbitration, or defining when the relationship will be called international. The Albanian legislation provides definitions of the arbitral proceedings and the court of arbitration, which provides that arbitration, may be composed of a single judge or panel (article 404 CCP). Parties involved have the right to address a permanent arbitral institution or to appoint arbitrators accordingly 6 .

The arbitration agreements are provided in Articles 403 and 404 of the Civil Procedure Code. This agreement gives the court jurisdiction to proceed to arbitration. At this point we see the exclusion of non-contractual relations. We would have invalidity in the arbitration agreement in cases where there is no written form. The legislation does not provide a way of determining the arbitrators and the object of the dispute. There is mentioned when a judicial process has begun,

2 Spahiu, A., (2013), "Alternative Dispute Resolution and the Albanian Legal Reality", Mediterranean Journal of Social Sciences., Vol 4 No 10 October 2013, page 5.

${ }^{3}$ Law $\mathrm{nr}$ 7424, dated 14.11.1990 "On state arbitration", article 11/a

${ }^{4}$ Decision no.178, dt 24.10.1973 "On approval of the Regulation on the review of disputes by state arbitration", Official Journal, No.5, Page 79

${ }^{5}$ Law nr.7424, dated 14.11 .1990 "On state arbitration", article.28

${ }^{6}$ The same definition will see on European Convention on International Commercial. Arbitration 1961, article 6 
and each party claims to have an arbitration agreement.

The formation of the Arbitral Tribunal is governed by the provisions of the Civil Code of Procedure, articles nr 407414. These provisions govern the issue of the subject of arbitration, as the court proceedings that formed the mission of the arbitrator and its duration and the jurisdiction of the court. The Albanian lawmakers at this moment have not consumed all the key concepts in stages of the arbitration proceedings, which should be separated for each aspect. Here is mentioned: "the conditions and procedures of appointment, exclusion, removal, replacement and termination of the mandate of the arbitrators". At the same time our legislation provisions, which relate to the formation of the arbitral tribunal, are treated in different ways ${ }^{7}$. These provisions must exist in interactions with each other and be in harmony.

Jurisdictions of the court are predicted in Article 414 of the CPP, the issue of jurisdiction treated, is closely associated with the arbitration decision, injuring effects of other processes. In cases where there is an arbitration agreement, whether the arbitration procedure has begun, other jurisdictions should declare "non-competence", unless the arbitration agreement is manifestly void, or unenforceable. At this point emerges that national legislation, the issue of jurisdiction has been openly appreciated only between legal relationship between the agreement for arbitration and ordinary courts on the other. Therefore, a reassessment of the interpretations of Article 404 of the CCP is required.

Arbitral awards are final, and they shall be given by majority against the opinion of arbitrators, who shall be submitted in writing. They should also include all the content of their final decision with all its elements. Rejection of the arbitration decision may be made only in cases defined: in the same heading Albanian lawmaker defines the time to appeal the decision of the arbitration mentioned8: the causes of complaints, reviewing the appeal of the Court of Appeal, appeal deadlines, laying the decision on execution and allowing the appeal to the Supreme Court ${ }^{9}$.

In Albania was created the MEDART centre, as part of the Chamber of Commerce, an institution founded with the support by the World Bank. In all its activities, the centre fundamentally failed its purpose of creation, as it promoted very little its functionality to the Albanian businesses.

One of the main factors which influenced the MEDART disbelief was that the Albanian businesses could not trust the judicial system during that time, which was characterized by numerous difficulties. However, at the same time, in the absence of law enforcement by the courts, resolving the issues of a single judge and privately, would always be accompanied by veils of doubts for all businesses. These doubts were coming as a result of the fragile Albanian state after few years had passed since the civil war of 1997. Another factor is that the alternative resolution through arbitration is seen as an excessive investment, since in many cases and depending on the object, the trial will be more expensive compared to ordinary judgment. Important milestones on international arbitration in the Republic of Albania would be the accession to the Convention of New York Convention "On the Recognition and Enforcement of Foreign Arbitral Awards"10 and the Geneva Convention ${ }^{11}$. Regarding international arbitration, Article 439 states that it is regulated by a special law, but in fact such law does not yet exist. Despite the absence of legal framework, the Republic of Albania undertakes its rights and obligations in front of foreign arbitral awards. The above are just conventions, a source for legislation. This attitude has held the Republic of Albania during the arbitration conducted at the International Court of Arbitration between the parties S.Saranda against the Republic of Albania. This judgment was given by the Council of Ministers, for the payment of Administrative expenses ${ }^{12}$. This is a fair example of the application of conventions and not avoidance of the administrative process at the moment that there is an arbitration agreement.

\section{What Should be Done for a Reassessment of Arbitration?}

\subsection{Legislative Reflections}

The Albanian legislation provides for arbitration, as an integral part of the Code of Civil Procedures. Furthermore, it is considered as part of the judicial system, using the same procedures. In contrast with this system, the arbitration shall be treated free of these formalities. It must be evaluated as the creation of a single legislation of internal and international

\footnotetext{
${ }^{7}$ Article 403 and article 423 of Albanian CPP

${ }^{8}$ Article 434 of Albanian CPP

${ }^{9}$ Article $434-438$ of Albanian CCP

${ }^{10}$ Law no.8688 dated 09.11.2000 "On accession of the Republic of Albania in the "Convention on the Recognition and Enforcement of Foreign Arbitral Awards

${ }^{11}$ Law no.8687, dated 9.11.2000 "On accession of the Republic of Albania in the "European Convention on International Commercial Arbitration

${ }^{12}$ Decision of the Council of Ministers $\mathrm{nr} 914$ date 26.08.2009 "For payment of administrative expenses of international arbitration for issue "S.Saranda" LIc, vs Republic of Albania"
} 
arbitration, as the Albanian legislation there is a genuine law for international arbitration. Also, the Albanian legislation categorically excludes the use of arbitration for non-contractual matters.

Regarding the arbitration agreement, there are incomplete projections. The Albanian legislation recognizes only the written form of the agreement. Such practice in today's global economy is a very narrow theory. The agreement should liberalize and should be recognized in other verbal forms, to the point where agreement can be registered. It can't be properly evaluated, if we are dealing with an arbitration agreement in cases where the court has begun a process and each party is claiming the existence of the arbitration agreement, while not opposed to the other party. In an analytical assessment, there is no separation of the arbitration clause of the contract in its entirety. Furthermore, there are no expectations that bring the invalidity of the arbitration agreement in the absence of the ability to act.

An important point to be addressed is the relationship between arbitral, tribunal and ordinary courts, interventions and functions between each other. There is no definition and clarity, that when ordinary court plays a supporting role and that when an ordinary court plays a supervisory role.

A reflection will be required in Article 422 of the Civil Code of Procedure, relating to the development of the process of arbitration under this Article, determined that: "When the claimant or the defendant did not appear at the scheduled date and time of the hearing without any justifiable reason, the court develops the arbitration trial in absence. The failure of a party should not be considered as an admission of the claims of the other party ". In connection with it, the court must abide by the principle that it will cease judgment in the case when the claimant fails to appear. The same approach is also kept by the legislation of different countries such as Germany ${ }^{13}$, the Great Britain ${ }^{14}$, etc.

In arbitral awards, the Albanian legislation also provided its opposing opinion. Such an assessment is in contrary to the nature of arbitration as conciliatory process, creating a confusion among parties, as well as the losing out of "gain" of the process and not only that, but the opportunity of not accepting this decision. Another aspect lies in the fact that the final decision of the arbitration, signed by the majority of the arbitrators, has the same effect as if signed by all the arbitrators ${ }^{15}$. Such reflection requires the contrary arbitrator's obligation to file it, as a consequence of the obligation they have towards their counter parties. The right of appeal requires a review of legislators, because according to the Albanian legislation, the court decisions cannot be appealed. It is also time to review the underlying part of the appeal based on international law ${ }^{16}$.

\subsection{Theoretical reflections}

A large investment in arbitration it is still required. As well as on how it works and the advantages to the usual trials. Today there do not exist various forums or training programs, to prepare arbitrators able to resolve the issues. Lack of a trade forums, is another argument why arbitration is not developing properly.

Arbitration as a process should be developed by professionals from various fields such as economics, law, engineering and others. But, to create high quality arbitrators, the subject of arbitration will be required to be practiced at university, where students will learn and perhaps "embrace" it as a future profession. In many universities in Albania, the subject of arbitration is practiced as an optional subject. In other cases, it is involved only in a special chapter of Civil Law $^{17}$. All these, make it possible not only to refrain arbitration frequented as subjects, but also not known. The need and importance, in my opinion, is so great that this subject deserves to be treated as mandatory. If we talk about the Law of Arbitration in Albania, we would be able to refer to a few lectures by teachers of this subject. So, this means that the writings on this field in our country are very limited. Even fewer are the writings of International Arbitration in Business Law.

With the developments that the Albanian economy is going through, knowledge of business with the institution of arbitration will result counterproductive, since such a process shortens the time and costs for a long time, even months and years in Albanian ordinary courts. It is necessary to invest more on the recognition and enforcement of international arbitrage. Also, the need to take the analysis of countries that have experienced a similar transition with Albania, by analogy to foreign decisions taken on its application and recognition. Arbitration in Business Law constitutes an important area of law. Unlike other areas, which mainly comprise theoretical need for knowledge creation and legal basic concepts, the importance of the study of arbitration, particularly international arbitration, right there, in my opinion, it's of high

\footnotetext{
${ }^{13}$ Article 1048 of German Civil Code of Procedure.

${ }^{14}$ Article 41 of England Arbitration Act 1996

${ }^{15}$ Article 429 of Albanian CCP

${ }^{16}$ Article 34 of UNCITRAL MODEL LAW

17 Brati,A. (2008). "Civil Procedure", (1st ed.). Tiranë:Dudaj page 49.
} 
practical importance.

\section{Conclusion}

After an analysis of the arbitration in the current Albanian legislation, the time has come for a reassessment of it. Numerous changes in the economic and legal fields, as a consequence of the globalization, require a process and a greater embodiment of arbitration. The development of science and technology on the other hand and also different social relations, have fundamentally changed the relationship between state courts and arbitration. The Albanian state, as one of the countries with a fragile democracy, pledges to implement the principles of democracy. Applying these principles makes it possible to achieve its objective of political and economic interests, based on free trade. There have been applied a series of material laws and international conventions adhered more, because the Albanian government pledges to recognize and accept the new reality.

The Albanian judicial system after the economic transition was not able to support a burden like this as a result of an outdated structure inherited from an old system, and the absence of legislative resources. For these extraneous reasons, the judiciary system would produce a very prolonged decision, not transparent and often contradictory. This directly affects the process itself, in terms of: (i) in reducing the time invested in issues; (ii) the work does not get done properly; (iii) multiple delays ${ }^{18}$. Albanian legislation up to this moment has reached the target on the arbitration process but it will require an investment of even greater legislative structure, to improve, as any other arbitration process is characterized by its dynamism.

Priorities of democracy and free market generate more and more large amount of conflict for ordinary courts, but on the other hand will require a discretion and a choice in the courts of arbitration. For these reasons, it is important to emphasize that the Albanian ordinary courts, guided by a vicious complexity, take the time to direct more cases of ordinary courts to undergo arbitration proceedings. This is to change once and for all the exclusivity of state court in cases where there is the possibility to refer them for a review of the arbitration process. Despite the existence of legal problems, lack of practice and believes, it will be understood as a lack of confidence. A busy practice, seen adequate with a legislation, is still under construction, taking into consideration, as was estimated by the above, the legislative reflections will lead to an excellent arbitration process. Numerous practices, a great faith and a light can be highlighted on what the arbitration contains in itself.

\section{References}

Alban, B. (2008). "Civil Procedure", (1st ed.). Dudaj. Tiranë

Decision no.178, dt 24.10.1973 " On approval of the Regulation on the review of disputes by state arbitration", Official Journal, No.5, Page 79

Decision of the Council of Ministers nr 914 date 26.08.2009 "FOR PAYMENT OF ADMINISTRATIVE EXPENSES OF INTERNATIONAL ARBITRATION FOR ISSUE "S.SARANDA" LLC, VS REPUBLIC OF ALBANIA

England Arbitration Act 1996

German Civil Code of Procedure

Law No.8116, dated 29.03.1996 Civil Code of Procedure of the Republic of Albania

Law no.8687, dated 9.11.2000 "On accession of the Republic of Albania in the "European Convention on International Commercial Arbitration".

Law no.8688 dated 09.11.2000 "On accession of the Republic of Albania in the "Convention on the Recognition and Enforcement of Foreign Arbitral Awards"

Law nr.7424, dated 14.11.1990 "On state arbitration"

Steven. C. B (2002), "Arbitration: Essential Concepts" Alm publishing, New York

Suela, M.(2012). "The right of international commercial arbitration and mediation" Dudaj, Tiranë

UNCITRAL Model Law on International Commercial arbitration 1985 with amendments as adopted in 2006.

A.Spahiu. (2013). "Alternative Dispute Resolution and the Albanian Legal Reality". Mediterranean Journal of Social Sciences. Doi:10.5901/mjss.2013.v4n10p146.

${ }^{18}$ Mëneri., S (2012) "The right of international commercial arbitration and mediation" Dudaj. Tiranë. page 21. 